\title{
PLANTS OF NEW SOUTH WALES ILLUSTRATED.
}

\author{
No. viii.-Acacia lanigera, A. Cunn.; B.Fl. ii. 324.
}

By R. T. Baker, F.L.S., Assistant Curator, Technological Museum, Sydney.

\section{(Plate xxvir.)}

A rigid shrub of several feet, the branches terete, branchlets often angled and mostly woolly.

Phyllodia lanceolate, falcate, rigid, thick, dark green, tapering to a pungent point, $1 \frac{1}{2}$ to rarely $2 \frac{1}{2}$ inches long, mostly 2 to 3 lines rarely 4 lines broad, in some specimens woolly but in others glabrous; nerves very prominent, occasionally anastomosing, marginal gland rarely found, except in southern specimens.

Stipules subulate, about $1 \frac{1}{2}$ lines long, often persistent, woolly.

Peduncles axillary, short, weak, solitary, clustered, bearing a globular or elongated head of about 25 flowers, mostly 5 -merous.

Bracts at the base of the peduncles ovate, acuminate, ciliate, woolly.

Calyx campanulate, with obtuse, thickened, ciliate lobes, not half as long as the corolla.

Petals smooth, united to the middle.

Pod about 3 inches long, 3 to 4 lines broad, very woolly, much twisted, margins not thickened, slightly contracted between the seeds.

Seeds longitudinal, oblong in the centre of the pod, the funicle short, with 3 folds, the last fold short, but not thickened under the seed. 
Hab.-Coonabarabran, (S. Lyndon), Mudgee and Rylstone (R. T. B.); Cobar (Rev. J. M. Curran); Blue Mountains, Lachlan River and to Southward (A. Cunningham, Fraser, Huegel, Mitchell and others, teste Bentham).

I feel privileged in being able to complete the description, and to give a satisfactory figure of this species, and I hope now that these notes will remove any difficulties that may have existed in connection with its determination.

I have not seen A. Cunningham's description in Field's Geographical Memoirs on New South Wales, but I take it that Don's transcription of it is a correct one, judging from the numerous specimens that have come under my observation, and the very brief description of the pod is correct as far as it goes.

In the Bot. Mag. t. 2922, published in 1829, no pods are figured or described; and the illustration itself is of very little help in identifying the species.

Bentham's description of the pod in the Flora Australiensis (Vol. ii. p. 325) is referred to by Baron von Mueller in Proc. Linn. Soc., 2nd Series, Vol v. p. 19, in these words:-“" . . . Bentham placed the pods of Acacia Oswaldi with A. lanigera" so that this error has perhaps been the cause of the recent confusion surrounding this species, and a debt is due to Baron von Mueller for so important a note.

But to me it appears that Bentham must have had some pod other than A. Oswaldi before him, as the description under A. lanigera does not agree with the pod of A. Oswaldi in Baron von Mueller's Iconography of Australian Acacias, 6th Decade, and which figure agrees in every detail with all specimens of the fruit of $A$. Oswaldi that have come under my notice.

In Baron von Mueller's note above quoted he gives $A$. venulosa and $A$. Whanii as synonyms of this species.

This latter species I have not seen, but from the imperfect specimens of A. venulosa collected by me, I am inclined to think that $A$. venulosa of Bentham is a good species. 


\section{EXPLANATION OF PLATE.}

Plate Xxvir.

Acacia lanigera, A. Cunn.

Fig. 1.-Flowering twig.

Fig. 2.-Part of a branch enlarged, to show bracts and stipules at the base of the peduncle.

Fig. 3.-Bud.

Fig. 4.-Expanded flower.

Fig. 5.-Pistil.

Fig. 6.-Cluster of pods.

Fig. 7.--Seed in situ.

Fig. 8.-Individual phyllode.

Fig. 9.-Portion of phyllode enlarged.

(Figs. 2, 3, 4, 5 and 9 enlarged.) 


\section{$2 \mathrm{BHL}$ Biodiversity Heritage Library}

Baker, Richard T. 1895. "Plants of New South Wales illustrated. No. VIII." Proceedings of the Linnean Society of New South Wales 10, 382-384. https://doi.org/10.5962/bhl.part.24353.

View This Item Online: https://www.biodiversitylibrary.org/item/30097

DOI: https://doi.org/10.5962/bhl.part.24353

Permalink: https://www.biodiversitylibrary.org/partpdf/24353

\section{Holding Institution}

MBLWHOI Library

\section{Sponsored by}

MBLWHOI Library

\section{Copyright \& Reuse}

Copyright Status: NOT_IN_COPYRIGHT

This document was created from content at the Biodiversity Heritage Library, the world's largest open access digital library for biodiversity literature and archives. Visit BHL at https://www.biodiversitylibrary.org. 